\title{
Genetic engineering and genome editing techniques in peanut plants
}

\author{
Abraham Lamboro ${ }^{1 *}$, Baixing Song ${ }^{1}$, Yang Songnan ${ }^{1}$, Xiao $\mathrm{Han}^{1}$, Hao Mingguo ${ }^{1}$, Xueying $\mathrm{Li}^{1}$, Dan $\mathrm{Yao}^{2}$ \\ \& Jun Zhang ${ }^{1^{*}}$ \\ ${ }^{1}$ Department of Crop Genetics and Breeding, College of Agronomy, Jilin Agricultural University, Changchun 130118, China \\ ${ }^{2}$ Department of Biochemistry and molecular biology, College of life science, Jilin Agricultural University, Changchun 130118, China \\ *Email: zhangjun@jlau.edu.cn, abraham.lire8@gmail.com
}

\section{ARTICLE HISTORY}

Received: 08 February 2021

Accepted: 23 April 2021

Available online: 01 July 2021

\section{KEYWORDS}

Agrobacterium

Biolistic

CRISPR/Cas9

Peanut

TALENs

ZFN
ABSTRACT

Research has long been associated with human life. In the effort to make a living, many experts who have contributed to the modernization of traditional research methods by conducting various research activities. In this process, professionals, from farmers to senior researchers, have done their part by developing plants that can tolerate or resist to disease. The growing population, climate change and plant disease are having a devastating effect on food security. In particular, it is essential to increase food production by producing high yielding crops of good quality, that may ensure food security. Recently, different gene- editing technologies have been developed. These techniques have been applied in many research fields and their development has provided economic benefits to farmers. Agrobacterium-mediated and biolistic methods are very important techniques for transforming genetic materials in plants. Genome- editing technologies are recent and highly applied in plant research to improve genes associated with yield, disease resistance and drought resistance. For example, Zincfinger Nucleases (ZFNS), Transcription Activator-like Effector Nucleases (TALEN), and Clustered Regularly Interspaced Short Palindromic Repeats system (CRISPR/ Cas9) methods are now widely applied by researchers and are playing a positive role in increasing production and productivity. Of the gene- editing technology, CRISPR/ Cas9 is widely applied in plant breeding programme as it is easy to use and cost-effective. In this review, we mainly focus on peanut plant, which is an important oilbearing allotetraploid crop. Therefore, peanut gene editing-technology could increase the oleic acid content in edible peanut oil. Thus, genome editing and gene transformation technologies are extensively explored in this review.

\section{Introduction}

Due to the development of different gene transformation and gene removal or addition methods, researchers are applying to solve plant disease problems, to increase the yield and quality of the product. Recently, gene- editing technology has proved to be a promising method. CRISPR/ Cas9 in particular is being used and is growing. Cas9 endonuclease and guide RNA can be delivered into plant cells as DNA, RNA or robonucleoprotein (RNP) to cleave target DNA sequence (s) in the genome. However, in addition to the intended target (on-target) site, Case 9 can potentially cause off-target double strand breaks (DSBs) at genomic locations with significant sequence similarity to that of the intended target sequence $(1,2)$. Cause of off-target (creating unexpected mutation) may be a drawback of the technology which need improvement mechanism and further investigation to minimize related problem in the future breeding programme in plants.
Through germ plasm screening, plant breeders have identified crops having economically important traits. For example, legumes especially peanut with high oleic acid content was identified. This high oleate spontaneous mutant line (F435) contain $80 \%$ oleic acid (3). In this mutant line, two types of mutation were reported at 448 base pair $(\mathrm{bp})$ in the ahFAD2A gene and insertion between (441_442insA), in the ahFAD2B gene (4). Using mutant line as one of the parents helps to improve important trait in conventional breeding in the peanut genome. Since then, many high oleic acid to linoleic acid ratio (O/L) cultivars have been developed (5). Increasing oleic acid content in the peanut genome has a great effect to enhance the shelf life and has health benefits too. Reports are there on the new G451T mutation induced by CRISPR/Cas9 based gene-editing in the coding region of Arachis hypogaea FAD2B gene in the peanut (6). Using recently developed gene-editing technologies, peanut breeders will improve the oleic acid to linoleic acid ratio (O/L). China has produced several high oleate (HO) peanut cultivars and countries 
like Argentina, Australia, Brazil, Israel, Japan and South Africa are also producing high oleate peanut products for consumption (7). Allotetraploid Arachis hypogaea $(\mathrm{AABB}, 2 \mathrm{n}=4 \mathrm{x}=40$ ) has two common diploid $(2 \mathrm{n}=2 \mathrm{x}=20)$ ancestors (Arachis dura-nensis and Arachis ipaensis having (AA) and (BB) genome respectively (812).

The desaturase enzyme encodes ahFAD2A and ahFAD2B genes (4). This enzyme plays a great role in the conversion of oleic acid to linoleic acid. To reduce the linoleic acid and to increase oleic acid in the peanut genome, gene-editing method has a great effect on the future breeding programme. Therefore, the main focus of the current review is to assess genetic engineering and genome editing techniques in peanut.

Peanut oil contains about 12 fatty acids, of which nearly $80 \%$ is composed of oleic acid a mono unsaturated fatty acid (36-67\%) and linoleic acid a poly unsaturated fatty acid (15-43\%). Further, palmitic acid a saturated fatty acid contributes nearly $10 \%$, whereas remaining $10 \%$ are constituted of up to nine other fatty acids $(7,13)$. The nutritional quality, flavor and shelf-life of peanut seeds and its products dependent on the presence of relative proportion of various fatty acids like saturated fatty acids, monounsaturated fatty acids and polyunsaturated fatty acids in its oil (14).

\section{Peanut transformation via particle bombardment}

Plant breeders are widely using different gene transformation techniques to transfer biologically important traits for various reasons. Producing high yielding crops with good quality, fungus resistance, bacterial resistance, pest resistance etc. are the main goal of plant breeding. Two genetic transformation methods (particle bombardment and Agrobacterium mediated transformation) have been widely applied to produce economically important trait. Genetic transformation by particle bombardment consists of the introduction of DNA in to intact cells and tissues by accelerated microparticles driven at high speed (15). The use of micro-projectile bombardment as a means of developing transformed peanut plant was first reported (16). Particle bombardment method was developed using immature peanut seeds as the source of explants. In the nucleus, exogenous DNA fragments are liberated and may be integrated in to chromosomal DNA through the process of illegitimate or homologous recombination, which depend exclusively on cellular components $(17,18)$. Some reports on micro-projectile bombardment of peanut tissue include: bombarding leaflets from mature embryos $(19,20)$, somatic embryogenesis regeneration system (21). Transformation through this technique is considered a more suitable to study gene function and transient gene expression (22). The main advantage of this technology is ability to transfer gene to a cell or tissue type and easier and quicker to use (23).

\section{Peanut transformation via Agrobacterium mediated transformation}

The agrobacterium mediated transformation has the ability to transform gene in plants (24). It can transfer DNA located on the tumour-inducing plasmid into the nucleus of the plant. Since this type of transformation is most effective and easy to use nowadays, it is widely used in the molecular biology laboratories. Compared to particle bombardment, this technique is powerful and have a significant role in the production of transgenic plants (24).

Peanut is considered to be recalcitrant for tissue culture and genetic transformation. Many species are either resistant to this gene transformation system or show low transformation efficiency (25). However, using different explant sources such as deembryonated cotyledons (26-28), embryo axes (9) and cotyledons (30) successful genetic transformation via Agrobacterium-mediated method has been reported in peanut research. Cotyledonary nodes (CNs) have relatively better regeneration ability than another explant source (31).

Several scientific reports on Agrobacteriummediated transformation in peanut by using various explant sources have been reported, including a cotyledonary node (32-34), de-embryonated cotyledon (34-36), Leaflet (34), immature leaves (35, 29), decapitated half embryo (37), mesocoty (38), embryonic axes $(39,40)$, leaf and cotyledon (41), embryo axes (42), leaf (43), de-embryonated cotyledon (44). In addition to peanut, Agrobacterium mediated transformation has been widely applied in many crops. Some of these include soybean (45), barley (46), wheat (47), sorghum (48-50), maize (51, $52)$, rice (53).

Genetic transformation is a powerful tool for the investigation of gene function in crops, but in some systems its impact is reduced by limited transformation capability (54). With legumes Agrobacterium tumefaciens mediated transformation has been used for the study of gene function (55). Moreover, wider availability and cost effectiveness are also two advantages that can be achieved through this mechanism of gene transfer (56).

\section{Zinc-finger Nucleases}

Engineered zinc fingers were combined with the DNA cleavage domain of FokI, a type IIs restriction endonuclease, to form ZFNs. It targets specific DNA sequences and alter the genome by creating double strand break (DSB) at specific location. Double stranded breaks facilitates DNA-repair process in the cell by non-homologous end joining creating a loss of function mutations. In contrast, homology directed repair can create a precise mutation. One of the problems is to cleave off-target sites leading to cellular toxicity (57). Using this method large number of plants have been edited successfully. For example, rice (58), Arabidopsis thaliana (59-61), soybean (62), wheat (63), perennial fruit trees (64), tomato (65), tobacco (66), rapeseed (67).

\section{Transcription Activator-like Effector Nucleases}

This is restriction enzymes that can cut desired DNA sequence in the genome. TALEs protein contain DNAbinding domain which is composed of many tandems of amino acid repeats (68). It is highly specific and targets a nucleotide at the specific target site in the genome. Like ZFNs, TALENs targets the genome through protein-DNA interactions. Its off-target site recognition in the genome was reported challenge in TALEN and other gene editing technologies (ZFNs) 
that need further studies to overcome unexpected gene mutation in the genome of the organism (69, 57). In many plant species including peanut, this gene editing- technology has been used (70, 71). Geneediting by using TALEN has been reported for various crops include: peanut (72), rice (73-77), soybean (78), maize (79), Wheat (80), barley (81-83) Arabidopsis thaliana (84).

\section{Clustered Regularly Interspaced Short Palindromic Repeat (CRISPR/Cas)}

The CRISPR/ Cas9 system was derived from the prokaryotic type II CRISPR system which is developed from a gene editing system in bacteria. It is a recently developed technique giving the opportunity for researchers to alter an organism's genome for the intended purpose of study. This technology helps breeders to add, remove or change genetic materials at a specific location in the genome. Compared with ZFNs and TALENs the CRISPR/Cas9 system is characterized by its simplicity, efficiency and low cost and by its ability to target multiple gene (85). Gene-editing technology has a broad application prospects in peanut oleic acid improvement. In 2013, using CRISPR/ Cas9 the first gene editing in the model plants Arabidopsis thaliana (86) and Nicotiana benthamina (87) were reported. Since then, it is widely applied in many plant species for gene function analysis and its current wide usage in the breeding of crop species has promising application for the future breeding programmes.

In CRISPR/Cas9, the low specificity of sgRNA may cause off-target DNA sequence. Due to this effect an unexpected or unwanted mutation will occur in the genome of the organism. Even though cas9 nickase developed to reduce the off-target effect, still it needs further investigation to avoid unnecessary mutation (88). Recently many crops that have been improved by CRISPR/Cas9 include: Arabidopsis and soybean (89), barley (90), Brassica napus (91), maize (92), peanut (6), rice (93), sorghum (94), soybean (95-97), wheat $(98,99)$. These reports provide evidence that the CRISPR/Cas9 could be used for targeted genome editing in crops.

Genome-editing approaches utilizing sitedirected endonucleases capable of making chromosomal double-strand breaks $(71,119,120)$ can help overcome the limitations of conventional breeding and accelerate development of improved crops. By harnessing natural cellular DNA repair process, double stranded breaks (DSBs) can be used to introduce targeted disease resistance, genome edits ti improve agronomic traits such as yield, nutritional content $(121,122)$ (Table 1).

\section{Conclusion}

Among gene-editing technologies, ZFNs and TALENs target the genome through protein-DNA interactions, whereas genomic DNA editing by the CRISPR-Cas system is based on short RNA-DNA base pairing (69). Targeting one gene at two positions increase the overall mutation frequency and allows the recovery of homozygous mutants in one generation $(123,124)$. The ease of multiplexing with the CRISPR/Cas9 system is therefore an advantage for the generation of knockouts using this dual-gRNA approach. In contrast to ZFNs and TALENs, Cas9 generates blunt double strand breaks that are typically repaired by the formation of small (usually 1-bp) indels, leading to the frequency recovery of frame shift mutants when the target site is within an exon (125).

Table 1. Genome editing technology in different plant species.

\begin{tabular}{|c|c|c|c|}
\hline Plant & Method of editing & Purpose of editing & References \\
\hline Peanut & CRISPR/Cas9 & Mutagenesis of $F A D_{2}$ genes & $(6)$ \\
\hline Tomato & CRISPR/Cas9 & Generate long-shelf life tomato & $(100)$ \\
\hline Potato & TALEN & Targeting sterol side chain reductase 2 (SSR2) gene & $(101)$ \\
\hline Arabidopsis & CRISPR/Cas9 & Generate inheritable mutants of Arabidopsis & (89) \\
\hline Soybean & CRISPR/Cas9 & Generate inheritable mutants of soybean & $(89)$ \\
\hline Peanut & TALEN & Mutagenesis of fatty acid desaturase 2 & (72) \\
\hline Soybean & CRISPR/Cas9 & Detect Glyma06g14180,Glyma08g02290 and Glyma12g37050 gene & $(102)$ \\
\hline Maize & CRISPR/Case 9 & Evaluate specificity of CRISPR-cas9 editing & $(103)$ \\
\hline Maize & CRISPR/ Case9 & Streamlines trait gene identification & $(104)$ \\
\hline Maize & TALEN & Induced targeted mutations in $\mathrm{ZmPDSZmIPK1A} \mathrm{ZmIPK \& ZmMRP4}$ genes & $(79)$ \\
\hline Barley & CRISPR/Cas9 & Generating homozygous knockout mutants & $(105)$ \\
\hline Melon & CRISPR/Cas9 & knockout phytoene desaturase gene & $(106)$ \\
\hline Barley & CRISPR/cas9 & Elucidate genetic control of vitamin E composition & $(107)$ \\
\hline Rice & ZFNs & Mutagenesis of SSIVa gene & $(58)$ \\
\hline Wheat & TALEN & Evaluate mutation screening & $(108)$ \\
\hline Barley & CRISPR/Cas9 & Creating targeted gene knockout & $(109)$ \\
\hline Wheat & CRISPR/Cas9 & Examine the role of temperature to editingefficiency & $(110)$ \\
\hline Tomato & ZFNs & Targeted LEC1-LIKE4 gene & $(65)$ \\
\hline Apple & CRISPR/Cas9 & Mutagenesis of $M d C N G C 2$ & (111) \\
\hline Apple & CRISPR/Cas9 & Induction of phytoene desaturase (PDS) gene & $(112)$ \\
\hline Rice & CRISPR/Cas9 & Improvement of rice blast resistance targeting the OsERF922 gene & $(113)$ \\
\hline Arabidopsis & ZFNs & Targeted mutations & (59) \\
\hline Apple & CRISPR/ Cas9 & Reduced fire blight susceptibility & (114) \\
\hline Grape vine & CRISPR/Cas9 & Mutagenesis of TAS4 and MYBA7 loci & $(115)$ \\
\hline Sorghum & CRISPR/Cas9 & $\begin{array}{l}\text { Target cinnamyl alcohol dehyderogenase }(C A D) \text { and phytoene desaturase } \\
(P D S) \text { genes }\end{array}$ & $(116)$ \\
\hline Cabbage & CRISPR/Case9 & Cy3-Cas9 protein delivery in to the nucleus & $(117)$ \\
\hline Wheat & TALEN & gene editing & $(80)$ \\
\hline Rice & CRISPR/Cas9 & knock out OsSWEET14 gene & $(107)$ \\
\hline Tomato & CRISPR/Cas9 & test novel sequence-specific mutations at eIF4E1 & $(118)$ \\
\hline
\end{tabular}




\section{Acknowledgements}

We would like to thank professor Jun Zhang and the research team for guidance and encouraging throughout the paper work. This research was funded through Jilin Province key research and development project (20180201070 NY).

\section{Authors' contributions}

AL, BS, YS, XH, HM, JZ, XL \& DY wrote and revised the manuscript. AL and JZ revised and edited the manuscript. All authors read and approved the final manuscript.

\section{Conflict of interests}

The authors declare no conflict of interest.

\section{References}

1. Zheng T, et al. Profiling single-guide RNA specificity reveals a mismatch sensitive core sequence. Sci Rep. 2017;7:40638.

2. Zhang S, Zhang R, Song G, Gao J, Li W, Han X, Chen M, Li Y, Li G. Targeted mutagenesis using the Agrobacterium tumefaciensmediated CRISPR-Cas9 system in common wheat. BMC Plant Biol. 2018;18(1):302. https://doi.org/10.1186/s12870-018-1496-x

3. Norden AJ, Gorbet DW, Knauft DA, Young CT. Variability in oil quality among peanut genotypes in the Florida breeding program. Peanut Sci. 1987;14:11-17.

4. Jung S, Powell G, Moore K, Abbott A. The high oleate trait in the cultivated peanut (Arachis hypogaea L.) II. Molecular Bais and genetics of the trait. Mol Gen Genet. 2000;263:806-11.

5. Chu Y, Holbrook CC, Ozias-Akins P. Two alleles of ahFAD2B control the high oleic acid trait in cultivated peanut. Crop Sci. 2009;49:2029-36.

6. Yuan M, Zhu J, Gong L et al. Mutagenesis of FAD2 genes in peanut with CRISPR/ Cas9 based gene editing. BMC Biotechnol. 2019;19:24. https://doi.org/10.1186/s12896-019-0516-8

7. Janila P, Pandey MK, Shasidhar Y Variath MT, Sriswathi M, Khera $\mathrm{P}$ et al. Molecular breeding for introgression of fatty acid desaturase mutant alleles (ahFAD2A and ahFAD2B) enhances oil quality in high and low oil containing peanut genotypes. Plant Science. 2016; 242:203-13. http://dx.doi.org/10.1016/j.plantsci.2015. 08.013

8. JRobledo G, Lavia G, Seijo G. Species relations among wild Arachis species with A genome as revealed by Fish mapping of rDNA loci and hetrochromatin detection. Theor Appl Genet. 2009;118:1295-1307.

9. Grabiele M, Chalup L, Robledo G, Seijo G. Genetic and geographic origin of domesticated peanut as evidenced by $5 \mathrm{~s}$ rDNA and chloroplast DNA sequences. Plant Syst Evol. 2012;1151-65.

10. Seijo G, et al. Genomic relationship between the cultivated peanut (Arachis hypogaea, Leguminosae) and its close relatives revealed by double GISH. J Bot. 2007;94:1963-71.

11. Ramos ML, et al. Chromosomal and phylogenetic context for conglutin genes in Arachis based on genomic sequence. Mol Genet Genome. 2006;275:578-92.

12. Samoluk SS et al. First insight in to divergence, representation and chromosome distribution of reverse transcriptase fragments from L1 retrotransposons in peanut and wild relative species. Genetica. 2015;143:113-25.

13. Moore KM, Knauft DA. The inheritance of high oleic acid in peanut. J Hered. 1989;80:252-3.2.
14. Derbyshire EJ. Areview of the nutritional composition, organoleptic characteristics and biological effects of the high oleic peanut. IJF Sci and Nutri. 2014;781-90.

15. Sanford JC. The biolistic process. Trends Biotechnol. 1988;6:299-302

16. Ozias-Akins P, Schnall JA, Anderson WF, Singsit C, Clemente TE, Adang MJ, Weissinger AK. Regeneration of transgenic peanut plants from stably transformed embryogenic callus. Plant Science. 1993;93:185-94.

17. Sanford JC. Biolistic plant transformation. Plant Physiol 1990;19:206-09.

18. Kohli A, Twyman RM, Abranches R, Weget E, Stoger E. Christou P. Transgene integration, organization and interaction in plants. Plant Mol Biol. 2003; 52; 247-58.

19. Livingstone DM, Birch RG. Plant regeneration and microprojectile-mediated gene transfer in embryonic leaflets of peanut (Arachis hypogaea L.). Australian Journal of Plant Physiology. 1995;22:585-91.

20. Clemente D, Robertson T, Islieb G, Beute-Marvin K. Evaluation of peanut (Arachis hypogaea L.) leaflets form mature zygotic embryos as recipient tissue for biolistic gene transfer. Transgenic Research.1992;1:275-84.

21. Deng X, Wei Z, An H. Transgenic peanut plants obtained by particle bombardment via somatic embryogenesis regeneration system. Cell Res. 2001;11:156-60.

22. Elghabi Z, Ruf S, Brock R. Biolistic co-transformation of the nuclear and plastid genomes. Plant J. 2011; 67:941-48.

23. Hadi MZ, McMullen MD, Finer JJ. Transformation of 12 different plasmids in to soybean via particle bombardment Plant Cell Rep. 1996;15:500-05.

24. Chilton MD, Drummond MH, Merio DJ, Sciaky D, Montoya AL, Gordon MP, Nester EW. Stable incorporation of plasmids DNA in to higher plant cells: The molecular basis of crown gall tumorigenesis. Cell. 1977;11:263-71.

25. Estrada-Navarrete G, Alvarado-Affantranger X, Olivares JE, et al. Agrobacterium rhizogenes transformation of the Phaseolus spp.: a tool for functional genomics. Mol Plant Microbe Interact. 2006;19:1385-93.

26. Sharma KK, Anjaiah VV. An efficient method for the production of transgenic peanut (Arachis hypogaea L.) through Agrobacrerium tumefaciens-mediated genetic transformation. Plant Sci. 2000;159:7-19.

27. Tiwari S, Tuli R. Factors promoting efficient in vitro regeneration from de-embryonated cotyledon explants of Arachis hypogaea L. Plant Cell Tissue Org. 2008;92:15-24.

28. Prasad K, Bhatnagar-Mathur P, Waliyar F, Sharma KK. Overexpression of a chitinase gene in transgenic peanut confers enhanced resistance to major soil and foliar fungal pathogens. J Plant Biochem Biotechnol. 2013;22:222-33.

29. Anuradha TS, Divya K, Jami SK, Kirti PB. Transgenic tobacco and peanut plants expressing a mustard defensing show resistance to fungal pathogens. Plant Cell Rep. 2008;27:1777-86.

30. Bhatnagar M, Prasad K, Bhatnagar-Mathur P, Narasu ML, Waliyar F, Sharma KK. An efficient method for the production of marker-free transgenic peanut (Arachis hypogaea L.). Plant Cell Rep. 2010;29:495-502.

31. Hsieh $\mathrm{Y}$, Jain $\mathrm{M}$, Wang $\mathrm{J}$ et al. Direct organogenesis from cotyledonary node explants suitable for Agrobacteriummediated transformation in peanut (Arachis hypogaea L.) Plant Cell Tiss Organ Cult. 2017;128:161-75.

32. Anuradha TS, Jami SK, Datla RS, Kirti PB. Genetic transformation of peanut (Arachis hypogaea L.) using cotyledonary node as explant and a promoterless gus::nptII fusion gene based vector.J Biosci. 2006; 31(2): 235-46. https://doi.org/10.1007/BF02703916.

33. Limbua PG, Ngugi MP, Oduor RO. in vitro regeneration protocol of Kenyan adapted groundnut (Arachis hypogaea L.) genetyes using cotyledonary node explants. J Plant Biochem Physiol. 2019;7:233. 
34. Marka R, Nanna RS. Optimization of factors affecting Agrobacterium-mediated genetic transformation in groundnut (Arachis hypogaea L.). Adv Plants Agric Res. 2018;8(3):275-82.

35. Mehta R, Radhakrishnan T, Kumar A et al. Coat proteinmediated transgenic resistance of peanut (Arachis hypogaea L.) to peanut stem necrosis disease through Agrobacteriummediated genetic transformation. Idian J Virol. 2013;24:205-13.

36. Rana $\mathrm{K}$, Mohanty LC. in vitro regeneration and genetic transformation in groundnut (Arachis hypogaea L. cv. Smruti) for abiotic stress tolerance mediated by Agrobacterium tumefaciens. J Today's Biological Science Research and Review. 2013;1:62-85.

37. Khan K, Islam A. Screening of Agrobacterium mediated transient transformation of peanut Arachis hypogaea). J Plant Sci Res. 2017;4:168.

38. Chen M, Yang Q, Wang T, Chen N, Pan L, Chi X, Yang Z Wang M, $\mathrm{Yu}$ S. Agrobacterium mediated genetic transformation of peanut and the efficient recovery of transgenic plants. Can J Plant Sci. 2015;95:735-44.

39. Geng L, Niu L, Gresshoff PM, Shu C, Song F, Huang D, Zhang J. Efficient production of Agrobacterium rhizogenes-transformed roots and composite plants in peanut (Arachis hypogaea L.). Plant Cell Tissue Organ Cult. 2012;109:491-500.

40. Rohini V, Rao KS. Transformation of peanut (Arachis hypogaea L.) : a non-tissue culture based approach for generating transgenic plants. Plant Sci. 2000;150:41-49.

41. Elisabeth AM, Cristiano L, Valéria G de F, Dulce E de $O$, Benedikt T, Antônio RC. Regulation of transformation efficiency of peanut (Arachis hypogaea L.) explants by Agrobacterium tumefaciens. Plant Science. 1993;89(1):93-99. https://doi.org/10.1016/0168-9452(93)90174-x

42. McKently AH, Moore GA, Doostdar H, Niedz RP. Agrobacterium-mediated transformation of peanut (Arachis hypogaea L.) embryo axes and the development of transgenic plants. Plant Cell Rep. 1995; 14(11): 699-703. https://doi.org/10.1007/BF00232650

43. Cheng M, Jarret RL, Li Z, Xing A, Demski JW. Production of fertile transgenic peanut (Arachis hypogaea L.) plants using Agrobacterium tumefaciens. Plant Cell Rep. 1996;15(9):635-37. https://doi.org/10.1007/BF00231918

44. Tiwari V, Chaturvedi AK, Mishra A et al. An efficient method of Agrobacterium-mediated genetic transformation and regeneration in local Indian cultivar of groundnut (Arachis hypogaea) using grafting. Appl Biochem Biotechnol. 2015; 175:436-53. https://doi.org/10.1007/s12010-014-1286-3

45. Paes de Melo B, LourenÃßo-Tessutti IT et al. Soybean embryonic axis transformation: Combining biolistic and Agrobacterium-mediated protocols to overcome typical complications of in vitro plant regeneration. Frontiers in Plant Science. 2020;11:1228. https://doi.org/10.3389/fpls.2020. 01228

46. Hinchliffe A, Harwood WA. Agrobacterium-mediated transformation of barley immature embryos. In: Harwood W. (eds) barley. Method in Molecular Biology. 2017;1900 (pp. 115126). Humana Press, New York, NY. https://doi. org/10.1007/978-1-4939-8944-7_8

47. Hensel G, Marthe C, Kumlehn J. Agrobacterium- mediated transformation of wheat using immature embryos.In: Bhalla P, Singh M.(eds) wheat biotechnology. Method in Molecular Biology. 2017; Vol 1679. https://doi.org/10.1007/978-1-49397337-8_8

48. Wu E, Zhao ZY. Agrobacterium-mediated sorghum transformation. In: Schmidt A. (eds) Plant germ line development. Method in Molecular Biology. 2017; vol 1669.https://doi.org/10.10 07/978-1-4939-7286-9_26

49. Ahmed RI, Ding A, Xie M, Kong Y. Progress in optimization of Agrobacterium-mediated transformation in sorghum (Sorghum bicolor). Int J Mol Sci. 2018; 19(10):2983. https://doi.org/10.3390/ ijms19102983

50. Sharma R, Liang Y, Lee MY et al. Agrobacterium-mediated transient transformation of sorghum leaves for accelerating functional genomics and genome editing studies. BMC Res Notes. 2020;13:116. https://doi.org/10.1186/s13104-020-04968-9.
51. Ishida Y, Hiei Y, Komari T. Agrobacterium-mediated transformation of maize. Nat Protoco. 2007; 2:1614-21. https://doi.org/10.1038/nprot.2007.241

52. Sidorov V, Duncan D. Agrobacterium-mediated maize transformation: immature embryos versus callus. In: scott MP. (eds) Transgenic maize. Method in Molecular Biology. 2009;526 (pp. 47-58). Humana Press, Totowa, NJ. https://doi.org/10.1007/978-1-59745-494-0_4

53. Feng M, Cang J, Wang J, Sun J, Yu J, Xu Q, Zhang D, Yang N, Lu Q, Lv Y. Regeneration and Agrobacterium-mediated transformation of Japanica rice varieties developed for a cold region. Czech J Genet Plant Breed. 2018;54:161-67.

54. Taylor CG, Fuchs B, Collier R et al. Generation of composite plants using Agrobacterium rhizogenes. Methods Mol Biol. 2006;343:155-67.

55. Somers DA, Samac DA, Olhoft PM. Recent advances in legume transformation. Plant Physiol. 2003;131:892-99.

56. Rafiq S. Analysis of factors influencing successful Agrobacterium mediated genetic transfor- mation in two different explants of peanut (Arachis hypogaea L.) variety BINA Chinabadam-2. BRAC University. 2014 http://hdl.handle.net/10361/3038

57. Gaj T, Gersbach CA, Barbas CF. ZFN, TALEN, and CRISPR/Casbased methods for genome engineering. Trends Biotechnol. 2013;31:397-405.

58. Jung YJ, Nogoy FM, Lee SK et al. Application of ZFN for site directed mutagenesis of rice SSIVa gene. Biotechnol Bioproc E. 2018;23:108-15. https://doi.org/10.1007/s12257-017-0420-9

59. Lloyd A, Plaisier CL, Carrol D, Drews GN. Targeted mutagenesis using zinc-finger nucleases in Arabidopsis. Proceedings of the National Academy of Science. 2005;102(6):2232-37. https://doi.org/10.1073/pnas.0409339102

60. Zhang F, Maeder ML, Unger-Wallace E, Hoshaw JP, Reyon D, Christian M,Li X, Pierick CJ, Dobbs D, Peterson T, Joung JK, Voytas DF. High frequency targeted mutagenesis in Arabidopsis thaliana Using zinc finger nucleases. In: Proceedings of National Academy of Science. 2010;107(26):12028-33. https://doi.org/10.1073/pnas.0914991107

61. Osakabe K, Osakabe Y, Toki S. Site-directed mutagenesis in Arabidopsis using custom-designed Zinc finger nucleases. Proceedings of the National Academy of Science. 2010;103(26): 12034-39. https://doi.org/10.1073/pnas.1000234107

62. Curtin SJ, Zhang F, Sander JD et al. Targeted mutagenesis of duplicated genes in soybean with Zinc-finger nucleases. Plant Physiology. https://doi.org/10.1104/pp.111.1729 81. 2011;156(2):466-73.

63. Ran Y, Patron N, Kay P et al. Zinc-Finger Nuclease (ZFN)mediated precision genome editing of an endogenous gene in hexaploid bread wheat (Triticum aestivum) using a DNA repair $\begin{array}{lll}\text { template. Plant } & \text { Biotechnology } & \end{array}$ https://doi.org/10.1111/pbi.12941

64. Peer R, Rivlin G, Golobovitch S, Lapidot M, Gal-On A, Vainstein A, Tzfira T, Flaishman MA. Targeted mutagenesis using zincfinger nucleases in perennial fruit trees. Planta. 2014; 241(4):941-51. https://doi.org/10.1007/s00425-014-2224-x

65. Hilioti Z, Ganopoulos I, Ajith S et al. A novel arrangement of zinc finger nuclease system for in vivo targeted genome engineering: the tomato LEC1-LIKE4 gene case. Plant Cell Rep. 2016;35:2241-55. https://doi.org/10.1007/s00299-016-2031-X

66. Townsend JA, Wright DA, FU RJ, Winfrey F, Maeder ML, Joung $\mathrm{JK}$ et al. High frequency modification of plant genes using engineered zinc-finger nucleases. Nature. 2009;459:442-45. https:// doi.org/10.1038/nature07845

67. Gupta M, Dekelver RC, Palta AC, Clifford S, Gopalan JC, Miller S, Novak D, Desloover D, Gachotte JC. Transcriptional activation of Brassica napus $\beta$-ketoacyl-ACP synthase II with an engineered zinc finger protein transcription factor. Plant Biotechnol J. 2012;10:783-91.

68. Bogdanove AJ. Principles and applications of TAL effectors for plant physiology and metabolism. Current opinion in Plant Biology. 2014;19:99-104. 
69. Chen K, Gao C. Targeted genome modification technologies and their applications in crop improvements. Plant Cell Rep. 2014;33:575-83.

70. Boch J, Scholze H, Schornack S, Landgraf A, Hahn S, Kay S, Lahaye T, Nickstadt A, Bonas U. Breaking the code of DNA binding specificity of TAL-type III effectors. Science. 2009;326:1509-12.

71. Christian M, Cermak T, Doyle EL, Schmidt C, Zhang F, Hummel A, Bogdanove AJ, Voytas DF. Targeting DNA double-strand breaks with TAL effector nucleases. Genetics. 2010;186:751-61.

72. Wen S, Liu H, Li X et al. TALEN-mediated targeted mutagenesis of fatty acid desaturase 2(FAD2) in peanut (Arachis hypogaea L.) promotes the accumulation of oleic acid. Plant Mol Biol. 2018;97:177-85. https://doi.org/10.1007/s11103-018-0731-Z

73. Ma L, Zhu F, Li Z, Zhang J, Li X, Dong J, Wang T. TALEN-based mutagenesis of lipoxygenase LOX3 enhances the storage tolerance of rice (Oryza sativa) seeds. Plos One. 2015;10(12). https://doi.org/10.1371/journal.pone.0143877

74. Nishizawa-Yokoi A, Cermak $\mathrm{T}$ et al. A defect in DNA ligase4 enhances the frequency of TALEN-mediated targeted mutagenesis in rice. Plant Physiology. 2016;170(2):653-66. https://doi.org/10.1104/pp.15.01542

75. Wang M, Liu Y, Zhang C, Liu J, Liu X, Wang L et al. Gene editing by co-transformation of TALEN and Chimeric RNA/DNA oligonucleotides on the rice OSEPSPS gene and the inheritance of mutations. Plos One. 2015;10(4):0122755. https://doi.org/10.1371/journal.pone. 0122755

76. Blanvillain-Baufumé S, Reschke M, Solé M, Auguy F, Doucoure H, Szurek B, Meynard D, Portefaix M, Cunnac S, Guiderdoni E, Boch J, Koebnik R. Targeted promoter editing for rice resistance to Xanthomonas oryzae pv. oryzae reveals differential activities for SWEET14-inducing TAL effectors. $\begin{array}{lll}\text { Plant Biotechnol } & \text { J. 2017;15(3):306-17. }\end{array}$ https://doi.org/10.1111/pbi.12613

77. Han J, Xia Z, Liu P et al. TALEN-based editing of TFIIAy5 changes rice response to Xanthomonas oryzae pv. oryzae. Sci Rep. 2020;10:2036. https://doi.org/10.1038/s41598-020-59052-w

78. Du H, Zeng X, Zhao M, Cui X, Wang Q, Yang H, Yu D. Efficient targeted mutagenesis in soybean by TALENs and CRISPR/Cas9. Journal of Biotechnology. 2016;217:90-97.

79. Liang Z, Zhang K, Chen K, Gao C. Targeted mutagenesis in Zea mays using TALENs and the CRISPR/Cas system. Journal of $\begin{array}{lll}\text { Genetics and } & \text { Genomics. }\end{array}$ https://doi.org/10.1016/j.jgg.2013.12.001

80. Luo M, Li H, Chakraborty S, Morbitz R et al. Efficient TALEN mediated gene editing in wheat. Plant Biotechnology Journal. 2019; pbi.13169. https://doi.org/10.1111/pbi.13169

81. Gurushidze M, Hensel G, Hiekel S, Schedel S, Valkov V, Kumlehn J. True-breeding targeted gene knock-out in barley using designer TALE-nuclease in haploid cells. Plos One. 2014 9(3):e92046. https://doi.org/10.1371/journal.pone.0092046

82. Budhagatapalli N, Rutten T, Gurushidze M, Kumlehn J, Hensel G. Targeted modification of gene function exploiting homology-directed repair of TALEN-mediated double-stranded breaks in barley. Genes Genomes Genetics. 2015;5(9):1857-63. https://doi.org/10.1534/g3.115.018762

83. Gurushidze M, Hiekel S, Otto I, Hensel G, Kumlehn J. Sitedirected mutagenesis in barley by expression of TALE nuclease in embryogenic pollen. In: Jankowicz-Cieslak J, Tai T, Kumlehn J, Till B.(eds). Biotechnology for Plant Mutation Breeding. 2017. https://doi.org/10.10 07/978-3-319-45021-6_7

84. Christian M, Qi Y, Zhang Y, Voytas DF. Targeted mutagenesis of Arabidopsis thaliana using engineered TAL effecter nuclease. G3Bethesda.

https://doi.org/10.1534/g3.113.0 07104.

2013:33(10):1697-705.

85. Cong L, Ran FA, Cox D, Lin S, Barretto R, Habib N, Hsu PD, Wu $\mathrm{X}$, Jiang W, Marraffin L. Multplex genome engineering using CRISPR/ Cas system. PubMed Science. 2013;339:819-23.

86. Li JF, Norville JE, Aach J, McCormack M, Zhang D, Bush J, Church GM, Sheen J. Multiplex and homologous recombination-mediated genome editing in Arabidopsis and Nicotiana benthamiana using guide RNA and Cas9. Nat Biotechnol Pub Med. 2013;31:688.
87. Nekrasov V, Staskawicz B, Weigel D, Jones JD, Kamous S. Targeted mutagenesis in the model plant Nicotiana benthamiana using Cas9 and RNA-guided endonuclease. Na Biotechnol. 2013;31:691-93.

88. Sugano SS, Osakabe K, Osakabe Y. Crop Breeding Using CRISPR/Cas9. InCrop Improvement Through Microbial Biotechnology 2018 Jan 1 (pp. 451-464). Elsevier. https://doi.org/10.1016/B978-0-444-63987-5.00023-2

89. Zheng Na, Ting Li, Jaime D, Dittman, Jianbin Su, Riqing Li, Walter G, Deliang P, Steven A, Whitham, Shiming Liu, Bing Yang. CRISPR/Cas9-based gene editing using egg ecll-specific promoters in Arabidopsis and soybean. Front Plant Sci. 2020; https://doi.org/ 10.3389/ fpls.2020. 00800

90. Han Y, Sue B, Li L, Xiao-Q Z, Jianbin Z, Xiaoyan H, Chengdao L. High efficient and genotype independent barley gene editing based on anther culture. Plant Communications. 2020; https://doi.org/10.1016/j.xplc.2020.100082

91. Yang $\mathrm{H}, \mathrm{Wu} \mathrm{JJ}$, Tang $\mathrm{T}$, et al. CRISPR/Cas9-mediated genome editing efficiently creates specific mutations at multiple loci using one sgRNA in Brassica napus. Sci Rep. 2017;7:7489. https://doi.org/10.1038/s41598-017-07871-9

92. Gao H, Mutti J, Joshua KY et al. Complex trait loci in maize enabled by CRISPR-Cas9 mediated gene insertion. Front Plant Sci. 2020; https://doi.org/10.3389/fpls.2020.00535

93. Komatsu A, Miki O, Zenpei S, Keiji N. Production of herbicidesensitive strain to prevent volunteer rice infestation using a CRISPR-Cas9 cytidine deaminase fusion. Front Plant Sci. 2020 https://doi.org/10.3389/fpls.2020.00925

94. Char Si N, Lee H, Yang B. Use of CRISPR/Cas9 for targeted mutagenesis in sorghum. Current Protocols in Plant Biology. 2020;5(2). https://doi.org/10.1002/cppb.20112

95. Wu $\mathrm{N}$, Lu Q, Wang $\mathrm{P}$, Zhang $\mathrm{Q}$, Shang J, Qu J, Wang $\mathrm{N}$. Construction and analysis of GmFAD2-1A and GmFAD2-2A soybean fatty acid desaturase mutants based on CRISPR/ Cas9 technology. Int J Mol Sci. 2020; 21(3):1104. https://doi.org/10.3390/ijms21031104

96. Li C, Nguyen V, Liu J, Fu W, Chen C, Yu K, Cu Y. Mutagenesis of seed storage protein genes in soybean using CRISPR/Cas9. BMC Res Notes. 2019;12:176. https://doi.org/10.1186/s 13104-0194207-2

97. Al Amin $\mathrm{N}$, Ahmad $\mathrm{N}, \mathrm{Wu} \mathrm{N}$, et al. CRISPR- Cas9 mediated targeted disruption of FAD2-2 microsomal omega- 6 desaturase in soybean (Glycine max L). BMC Biotechnoloy. 2019; 19(1):9. https://doi.org/10.1186/s12896-019-0501-2

98. Pankaj B, Evan E, Brittany P, Venkatesh B, Manjo K, Kaveh G, Halim S, Caixia G, Daniel F, Sateesh K. Targeted mutagenesis in wheat microspores using CRISPR/ Cas9. Scientific Reports 2018; 8:6502

99. Zhang S, Zhang R, Gao J, Gu T, Song G, Li W, Li D, Li Y, Li G. Highly efficient and heritable Targeted mutagenesis in wheat via the Agrobacterium tumefaciens-mediated CRISPR/ Cas system. Int J Mol Sci. 2019; 20(17):4257. https://doi.org/10.3390/ijms20174257

100. $\mathrm{Yu} \mathrm{QH}, \mathrm{Wang} \mathrm{B}$, Li $\mathrm{N}$ et al. CRISPR/Cas9-induced Targeted mutagenesis and gene replacement to generate long-shelf life tomato lines. Sci Rep. 2017; 7:11874. https://doi.org/10. 1038/s41598-017-12262-1

101. Yasumoto S, Sawai S, Lee HJ, Mizutani M, Saito K, Umemoto N, Muranaka T. Targeted genome editing in tetraploid potato through transient TALEN expression by Agrobacterium infection Plant Biotechnol 2020;37(2):205-11. https://doi.org/10.5511/plantbiotechnology.20.0525

102. Sun X, Hu Z, Chen R, Jiang Q, Song G, Zhang H, Xi Y.Targeted mutagenesis in soybean using the CRISPR-Cas9 system. Sci Rep. 2015; 5:10342. https://doi.org/10.1038/srep10342.

103. Young J, Zastrow-Hayes G, Deschamps S et al. CRISPR-Cas9 editing in maize: Systematic evaluation of off-target activity and its relevance in crop improvement. Sci Rep. 2019; 9:6729. https://doi.org/10.1038/s41598-019-43141-6

104. Liu HJ, Jian L, Xu J, Zhang Q et al. High throughput CRISPR/Cas9 mutagenesis streamlines trait gene identification in maize. The Plant Cell. 2020;32(5):1397-1413. https://doi.org/10.1105/tpc.19.00934 
105. Gasparis S, Kala M, Przyborowski M et al. A simple and efficient CRISPR/Cas9 platform for induction of single and multiple heritable mutations in barely (Hordeum vulgare L.). Plant Methods. 2018;14:111. https://doi.org/10.1186/s13007018-0382-8

106. Hooghvorst I, López-Cristoffanini C, Nogués S. Efficient knockout of phytoene desaturase gene using CRISPR/Cas9 in melon. Sci Rep. 2019; 9:17077. https://doi.org/10.1038/s41598019-53710-4

107. Zeng Z, Han N, Liu C, Buerte B, Zhou C, Chen J, Wang M, Zhang Y, Tang Y, Zhu M, Wang J, Yang Y, Bian H. Functional dissection of HGGT and HPT in barely vitamin E biosynthesis via CRISPR/ Cas9-enabled genome editing. Ann Bot. 2020;126(5):929-42. https://doi.org/10.1093/aob/mcaa115

108. Wang Y, Zong Y, Gao C. Targeted mutagenesis in hexaploid bread wheat using the TALEN and CRISPR/Cas systems. In: Wheat Biotechnology 2017 (pp. 169-185). Humana Press, New York, NY. https://doi.org/10.1007/978-1-4939-7337-8_11

109. Lawrenson T, Harwood WA. Creating targeted gene knockouts in barley using CRISPR/Cas9. In: Barley 2019 (pp. 217-232). Humana Press, New York, NY. https://doi.org/10.1007/978-14939-8944-7_14

110. Milner MJ, Craze M, Hope MS, Wallington EJ. Turning up the temperature on CRISPR: Increased temperature can improve the editing efficiency of wheat using CRISPR/ Cas9. Front Plant Sci. 2020;11:583374. https://doi.org/10.3389/fpls.2020.583374

111. Zhou H, Bai S, Wang N, Sun X, Zhang Y, Zhu J, Dong C. CRISPR/ Cas9-mediated mutagenesis of MdCNGC2 in apple callus and VIGS-mediated silencing of MdCNGC2 in fruits improve resistance to Botryosphaeria dothidea. Front Plant Sci. 2020 11:574-77. https://doi.org/10.3389/ fpls.2020.57

112. Nishitani C, Hirai N, Komori S et al. Efficient genome editing in apple using a CRISPR/Cas9 system. Sci Rep. 2016;6:31481.https://doi.org/10.1038/srep31481

113. Wang F, Wang C, Liu P, Lei C, Hao W, Gao Y, Liu YG, Zhao K, Wilson RA. Enhanced rice blast resistance by CRISPR/Cas9targeted mutagenesis of the ERF transcription factor gene OsERF922. Plos One. 2016;11(4):e0154027.

114. Pompili V, Dalla Costa L, Piazza S, Pindo M, Malnoy M. Reduced fire blight susceptibility in apple cultivars using a highefficiency CRISPR/ Cas9-FLP/FRT-based gene editing system. Plant Biotechnol J. 2020;18(3):845-58.

115. Sunitha S, Rock CD. CRISPR/ Cas9-mediated targeted mutagenesis of TAS4 and MYBA7 loci in grapevine rootstock 101-14. Transgenic Res. 2020;29:355-67. https://doi.org/10.1007/ s11248-020-00196-W

116. Liu G, Li J, Godwin ID. Genome editing by CRISPR/ Cas9 in sorghum through biolistic bombardment. In: Zhao ZY, Dahlberg J. (eds) Sorghum. Methods in Molecular Biology. 2019; vol. 1931. https://doi.org/10.1007/978-1-4939-9039-9_12
117. Lee MH, Lee J, Choi SA et al. Efficient genome editing using CRISPR-Cas9 RNP delivery into cabbage protoplasts via electrotransfection. Plant Biotechnol Rep. 2020;14:695-702. https://doi.org/10.1007/s11816-020-00645-2

118. Yoon YJ, Venkatesh J, Lee JH, Kim J, Lee HE, Kim DS, Kang BC Genome editing of eIF4E1 in tomato confers resistance to pepper mottle virus. Front Plant Sci. 2020;11:1098.

119. Kim YG, Cha J, Chandrasegaran S. Hybrid restriction enzymes Zinc finger fusions to Fok I cleavage domain. Proc Natl Acad Sci. 1996;93:1156-60.

120. Jinek $\mathrm{M}$ et al. A programmable dual-RNA guided DNA endonuclease in adaptive bacterial immunity. Science. 2012;337

121. Yin K, Gao C, Qiu JL. Progress and prospects in genome editing. Nat Plants. 2017;3:171-207.

122. Borrelli VMG, Brambilla V, Rogowsky P, Marocco A, Lanubile A. The enhancement of plant disease resistance using CRISPR Cas9 technology. 2018;9:1245.

123. Xie K, Minkenberg B, Yang Y. Boosting CRISPR/ Cas9 multiplex editing capability with the endogenous tRNA-processing system. Proc.Nat Acad Sci Pub Med. 2015;112:3570-75.

124. Brooks C, Nekrasov V, Lippman ZB, VanEck J. Efficient gene editing in tomato in the first generation using the clustered regularly interspaced short palindromic repeats/CRISPR associated system. Plant Physiol. 2014;166:1292-97.

125. Bortesi L, Zhu C, Zischewski J, Perez L, Bassie L, Nadi R, Forn G, Lade SB, Soto E, Jin X et al. Patterns of CRISPR/ Cas9 activity in plants, animals and microbes. J Plant Biotechnol PubMed. 2016;14:2203-16.

\section{Additional information}

Peer review information: Plant Science Today thanks Sectional Editor and the other anonymous reviewers for their contribution to the peer review of this work.

Reprints and permissions information is available at https://horizonepublishing.com/journals/index.php/PST/open_access_policy

Publisher's Note: Horizon e-Publishing Group remains neutral with regard to jurisdictional claims in published maps and institutional affiliations.

To cite this article: Lamboro A, Song B, Songnan Y, Han X, Mingguo H, Li X, Yao $D$, Zhang J. Genetic engineering and genome editing techniques in peanut plants. Plant Science Today. 2021;8(3):528-534. https://doi.org/10.14719/pst.2021.8.3.1127

Plant Science Today, published by Horizon e-Publishing Group, is covered by Scopus, Web of Science, BIOSIS Previews, Clarivate Analytics, etc. See https://horizonepublishing.com/journals/index.php/PST/indexing_abstracting 